\title{
Akuisisi Spektrum Near Infrared Reflectance Pada Bubuk Kopi Arabika (Kenary Coffee) Dan Bubuk Kopi Robusta (Kopi Ulee Kareng)
}

The Acquisition Of Near Infrared Reflectance Spectrum In Arabica Coffee Powder (Kenary Coffee) And Coffee Powder obusta (Kopi Ulee Kareng)

\section{Haitratun, Agus Arip Munawar, Zulfahrizal \\ Program Studi Teknik Pertanian, Fakultas Pertanian, Universitas Syiah Kuala}

\begin{abstract}
Abstrak. Kopi merupakan tanaman perkebunan yang sudah cukup lama dibudidayakan di Indonesia terutama di Aceh. Kopi yang ada di Aceh terdiri dari dua varietas yaitu kopi Arabika dan kopi Robusta. Pendeteksian bubuk kopi arabika dan bubuk kopi robusta secara cepat dan akurat menjadi kata kunci untuk menjawab kebutuhan produksi kopi masa depan. Pendeteksian mutu pangan yang cepat dan efesien dapat diwujudkan melalui pengembangan teknologi Near Infrared Reflectance Spectroscopy (NIRS). Tujuan dari penelitian ini adalah mengkaji spektrum bubuk kopi Arabika dan Robusta serta memprediksi panjang gelombang NIR yang relevan dengan atribut kualitas bubuk kopi. Spektrum bubuk kopi Arabika dan bubuk kopi Robusta mempunyai tipikal yang sama dimana puncak yang terbentuk pada spektrum sebagai informasi keberadaan kandungan zat-zat tertentu. Kandungan kafein pada bubuk kopi berada pada panjang gelombang 1430-1470 nm dan 1910-1965 nm. Kandungan lemak pada bubuk kopi berada pada panjang gelombang 1185-1230 nm, 1700-1780 dan 2290-2390 nm. Kandungan protein pada bubuk kopi berada pada panjang gelombang 1430-1470 dan 1910$1965 \mathrm{~nm}$. Kandungan asam amino berada pada panjang gelombang 2290-2390 nm.
\end{abstract}

Kata kunci : Akuisisi, Spektrum, NIRS.

Abstract. Coffee is a plantation crop that has long cultivated in Indonesia, especially in Aceh. Coffee in Aceh consists of two varieties are Arabica and Robusta. Detection of ground coffee arabica and robusta coffee powder quickly and accurately be a key to answering the needs of the future coffee production. The detection of food quality quickly and efficiently can be realized through the development of technology Near Infrared Reflectance Spectroscopy (NIRS). The purpose of this study is to examine the spectrum of Arabica and Robusta coffee powder and predict NIR wavelengths that are relevant to the quality attributes of the coffee powder. Arabica coffee powder spectrum and Robusta coffee powder which has the same typical peak formed at spectrum as presence information content of certain substances. The caffeine content in coffee powder is at a wavelength of 1430-1470 nm and 1910-1965 nm. The fat content in the coffee powder is at a wavelength of 1185-1230 nm, 1700-1780 and 2290$2390 \mathrm{~nm}$. Protein content in the coffee powder is at a wavelength of 1430-1470 and 1910-1965 $\mathrm{nm}$. The amino acid content is at a wavelength of 2290-2390 $\mathrm{nm}$.

Keywords: Acquisition, Spectrum, NIRS.

\section{PENDAHULUAN}

Indonesia merupakan salah satu negara pembudidaya tanaman kopi yang luas di dunia. Luas area tanaman perkebunan kopi di Indonesia pada tahun 2014 adalah seluas 1246,8.000 Ha. Aceh merupakan urutan ketiga terluas di Indonesia setelah Sumatera Selatan dan Lampung. Produksi kopi di Indonesia meningkat dari tahun 2013 diperkirakan sebesar 675,9.000 ton dan pada tahun 2014 sebesar 685,1.000 ton. Aceh sendiri pada tahun 2014 menyumbang sebanyak $54,9.000$ ton kopi dengan luas area 124,0.000 Ha. Pada tahun 2015 Ekspor kopi Indonesia untuk jenis Instant coffee adalah sebesar 54.579 ton dan roasted coffee sebesar 1.153 ton, Green Beans sebesar 218.352 ton dan extract, Essence, Concentrate sebesar 853 ton. Tujuan utama ekspor 
kopi Indonesia adalah USA, Jerman, Jepang, Italia, Philipina, Malaysia, dan Singapura (BPS, 2015).

Perkembangan areal tanaman kopi rakyat yang cukup pesat di Indonesia, perlu didukung dengan kesiapan sarana dan metode pengolahan yang cocok untuk kondisi petani sehingga mereka mampu menghasilkan biji kopi dengan mutu seperti yang dipersyaratkan oleh Standar Nasional Indonesia. Adanya jaminan mutu yang pasti, diikuti dengan ketersediaannya dalam jumlah yang cukup dan pasokan yang tepat waktu serta berkelanjutan merupakan beberapa prasyarat yang dibutuhkan agar biji kopi rakyat dapat dipasarkan pada tingkat harga yang menguntungkan.

Pada tahun 2012 volume ekspor kopi yang berasal dari Provinsi Aceh mencapai 18 ribu ton dan sebagian besar $(68,37 \%)$ diekspor ke negara Amerika Serikat. Banyaknya volume kopi yang di pasarkan ke pasar dunia menunjukkan bahwa eksportir memiliki peran strategis dalam pasar kopi Arabika Gayo. Di pasar kopi dunia, kopi Arabika Gayo tergolong kopi spesial yang telah memiliki sertifikasi produk. Oleh karena itu pengkajian kualitas bubuk kopi perlu dikembangkan untuk menjamin harga kopi. Pada tahun 2012 nilai jual kopi Arabika Gayo pernah mencapai 20\% (Rp 78.510) lebih tinggi dibandingkan harga kopi Arabika dunia (Rp 65.400) di pasar New York (AEKI, 2013).

Pendeteksian kualitas pangan yang cepat dan efesien dapat diwujudkan melalui pengembangan teknologi Near Infrared Reflectance Spectroscopy (NIRS). NIRS telah menjadi salah satu metode non-destruktif yang paling menjanjikan dan dapat digunakan untuk analisis dalam berbagai bidang, termasuk di bidang pertanian. Keuntungan yang dapat diraih adalah persiapan sederhana untuk sampel, proses deteksi cepat, dan ramah lingkungan karena tidak ada bahan kimia yang digunakan. Sebagai sebuah metode yang baru, penelitian NIRS terkait kopi belum banyak berkembang. Oleh karena itu pengembangan penelitian NIRS dengan objek kopi perlu didukung agar mampu menjawab tantangan masa depan.

\section{METODE PENELITIAN}

Penelitian ini dilaksanakan pada bulan Maret sampai Juni 2016. Bertempat di Laboratorium Instrumentasi dan Energi, Program Studi Teknik Pertanian, Fakultas Pertanian, Universitas Syiah Kuala, Banda Aceh.

\section{Alat dan Bahan}

Alat yang digunakan pada penelitian ini adalah FT-IR IPTEK T-1516 dan unscrambler software ${ }^{\circledR} X$ version 10.1 . Bahan yang digunakan pada penelitian ini adalah bubuk kopi Arabika Gayo dengan merek Kenary Coffee dan bubuk kopi Robusta dengan merek Kopi Ulee Kareng yang telah disangrai.

\section{Prosedur Penelitian}

Bubuk kopi Arabika Gayo dibagi menjadi 20 sampel dan bubuk kopi Robusta dibagi menjadi 14 sampel untuk diambil spektrumnya dengan berat persampel 10 gram. Kemudian dilakukan kalibrasi background/reference pada alat FT-IR IPTEK T-1516. Proses bekerjanya alat menggunakan integrating sphere. Digunakan software termo integration ${ }^{\circledR}$ untuk pengendalian kerja alat untuk pembuatan workflow dan menjalankan workflow, untuk running alat dilakukan oleh termo operation ${ }^{\circledR}$. Selang gelombang yang dipilih adalah antara 1000-2500 $\mathrm{nm}$ dengan interval $0.4 \mathrm{~nm}$. Workflow dibuat untuk mengatur alat agar bekerja untuk mengakuisisi spektrum Diffuse Reflectance, memindai sampel sebanyak 64 kali perproses lalu dirata-ratakan hasilnya, kemudian disimpan hasil pemindaian dalam 3 bentuk file yakni *.SPA. *.JDX dan *.CSV. Akuisisi spektrum bubuk kopi dengan pengambilan spektrumnya yaitu memasukkan bubuk kopi kedalam petridish yang tersedia. Lalu spektrum di transformasi 
menggunakan metode Derivative ke -2 dengan polonomial $=7$ dan cutting edge $=2$. Pengolah data spektrum menggunakan unscrambler software ${ }^{\circledR} X$ version 10.1 . Data diolah menggunakan Principal Component Analysis (PCA) dengan metode NIPALS dan maksimum PCs $=7$.

\section{HASIL DAN PEMBAHASAN}

\section{Spektrum Raw}

Spektrum bubuk kopi Arabika dan bubuk kopi Robusta mempunyai tipikal yang sama dimana puncak yang terbentuk pada spektrum sebagai informasi keberadaan kandungan zat-zat tertentu. Gambar 1 menunjukkan raw spektrum untuk bubuk kopi Arabika dan bubuk kopi Robusta, dimana diambil masing-masing satu sampel untuk mempermudah dalam interpretasi spektrum.

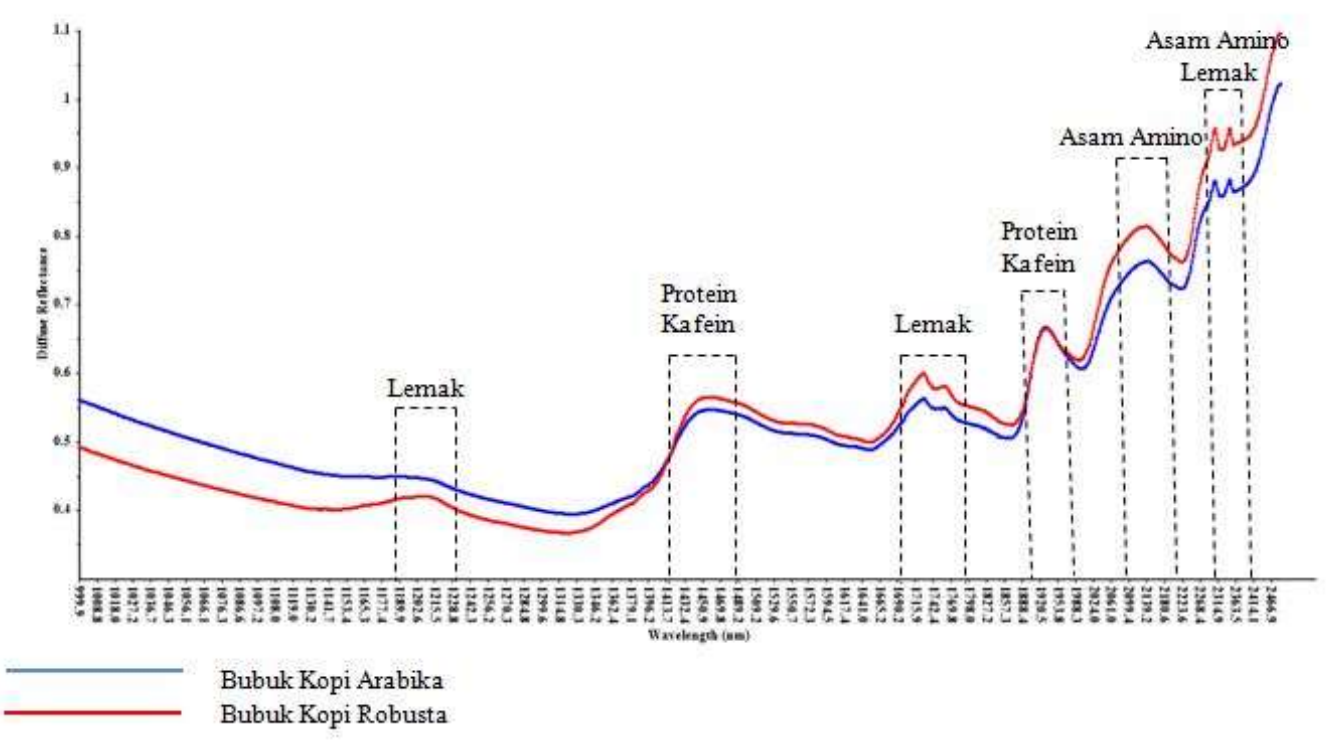

Gambar 1. Spektrum NIRS pada bubuk kopi

Kopi memiliki beberapa kandungan zat kimia yang terdiri dari: Kafein $\left(\mathrm{C}_{8} \mathrm{H}_{10} \mathrm{~N}_{4} \mathrm{O}_{2}\right)$, Lemak $(\mathrm{CH})$, Protein $(\mathrm{CHON})$, dan Asam Amino $\left(\mathrm{NH}_{2}\right)$. Ikatan kimia pada kualitas kopi ini 
secara garis besar tersusun dari unsur $\mathrm{C}, \mathrm{H}, \mathrm{N}, \mathrm{O}$. Unsur ini mengalami vibrasi pada rentang panjang gelombang near infrared yang berupa overtone, bending, dan stretching. Sehingga, memungkinkan bagi metode NIRS untuk memprediksi kadar kualitas pada kopi secara cepat dan simultan.

\section{Transformasi Spektrum (Derivative ke-2)}

Transformasi spektrum dilakukan untuk mengurangi pengaruh inteferensi gelombang (noises) pada data spektrum yang didapat agar diproleh model robust yang lebih akurat dan stabil. Derivative ke-2 telah berhasil menghilangkan baseline dan mempertajam perbedaan spektrum sehingga serapan spektrum tidak saling tumpang tindih maka pola spektranya terlihat lebih jelas dan puncaknya lebih banyak. Derivative ke-2 mampu memperjelas puncak dan lembah spektra absorban data NIRS. Spektrum tersebut dapat dilihat pada Gambar 2 dan Gambar 3.

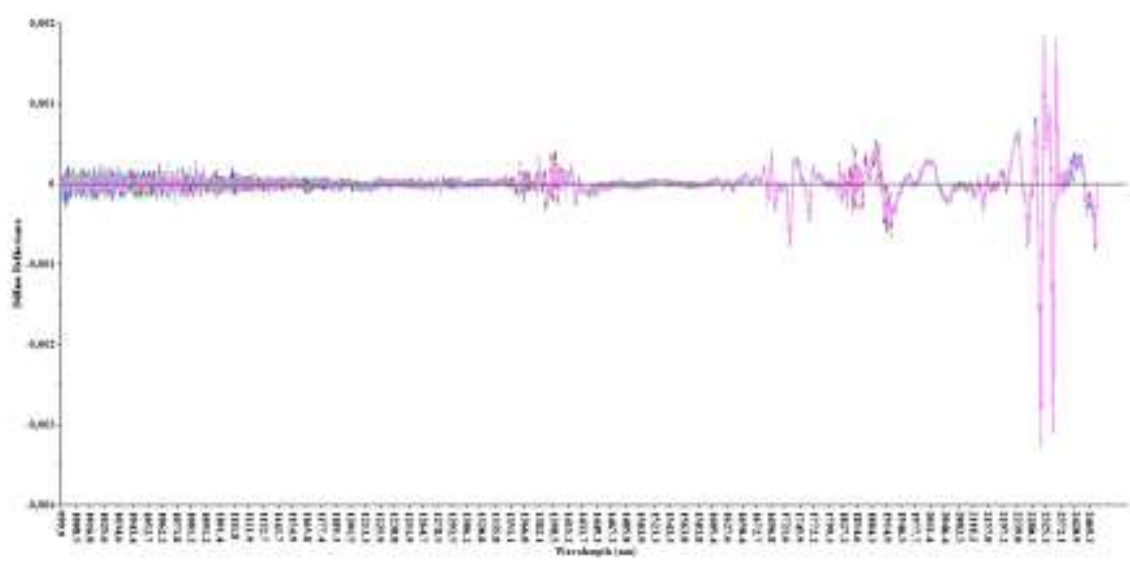

Gambar 2. Spektrum NIRS pada bubuk kopi Arabika + Derivative ke-2

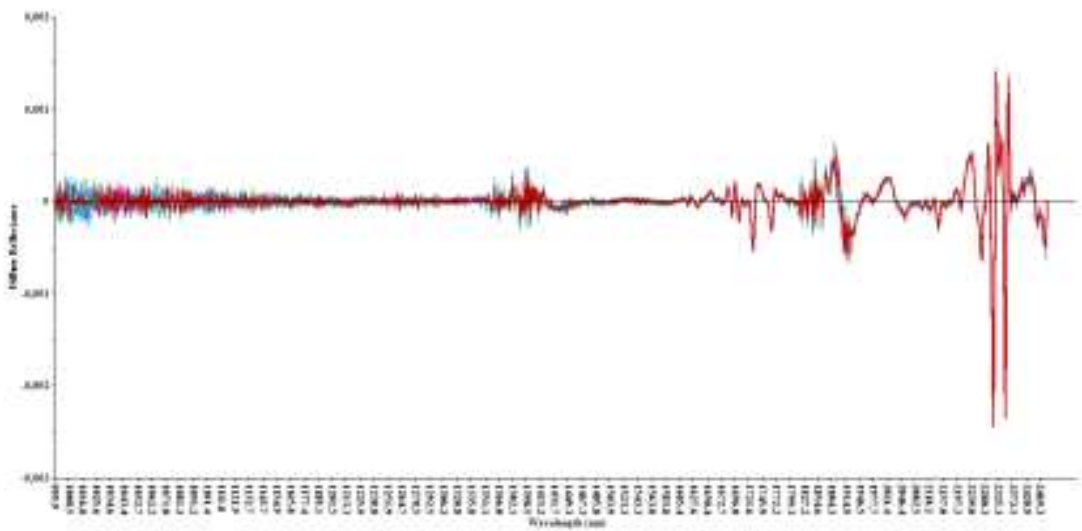

Gambar 3. Spektrum NIRS pada bubuk kopi Robusta + Derivative ke-2

\section{Klasifikasi Bubuk Kopi Seluruh Panjang Gelombang}

Pada klasifikasi data raw (data asli) menghasilkan total data yang dapat di analisa dengan total kumulatif explained variance menggunakan 2 PC pertama (PC1 dan PC2) adalah sebesar $100 \%$. Data ini terklasifikasi secara baik dengan prosentase keberhasilan sebesar 100\% (Gambar 4) secara rinci dimana bubuk kopi Arabika terklasifikasi sebesar $100 \%$ dan bubuk kopi Robusta juga dapat diklasifikasi dengan tingkat keberhasilan 100\%. 


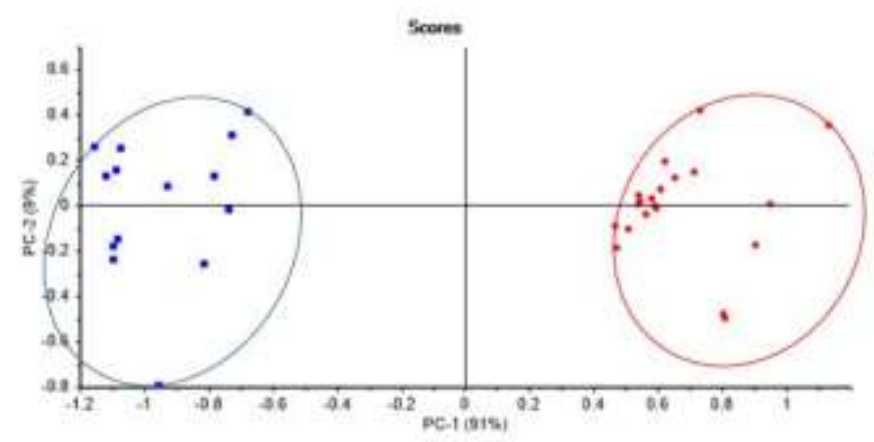

Keterangan Gambar :

: Arabika

: Robusta

Gambar 4. Hasil analisis PCA raw

Hal ini juga terlihat pada Gambar 5 hasil analisis PCA setelah transformasi spektrum kedalam bentuk Derivative ke-2 bentuk dari kedua bubuk kopi juga terklasifikasi dengan baik. Total data yang dapat di analisa dengan total kumulatif explained variance $2 \mathrm{PC}$ adalah sebesar $75 \%$. Data ini terklasifikasi secara baik dengan prosentase keberhasilan sebesar $100 \%$.

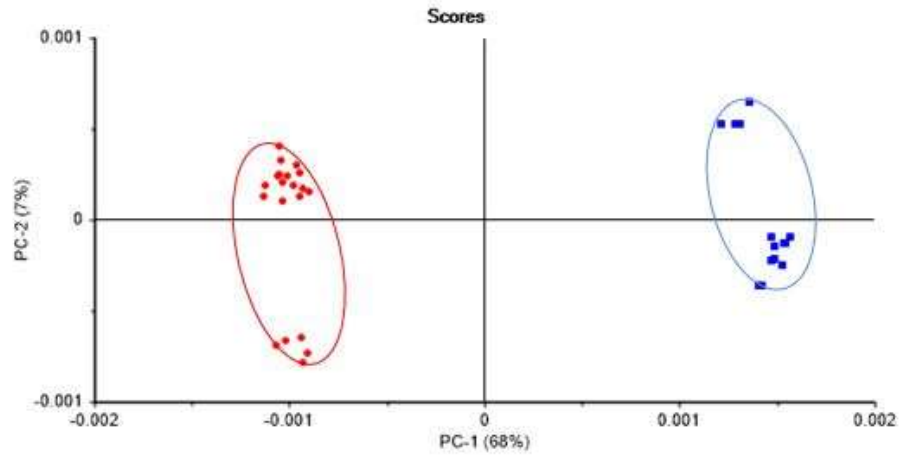

Keterangan Gambar :

- : Arabika

Gambar 5. Hasil analisis PCA Derivative ke-2

\section{Klasifikasi Bubuk Kopi Panjang Gelombang Pilihan}

Panjang gelombang 1000-1800 nm hasil analisis PCA raw terlihat bahwa kedua bubuk kopi dapat terklasifikasi secara baik. Total data yang dapat di analisa dengan kumulatif expalined variance 2 PC adalah sebesar $100 \%$. Data ini terklasifikasi secara baik dengan prosentase keberhasilan sebesar $100 \%$ (Gambar 6)

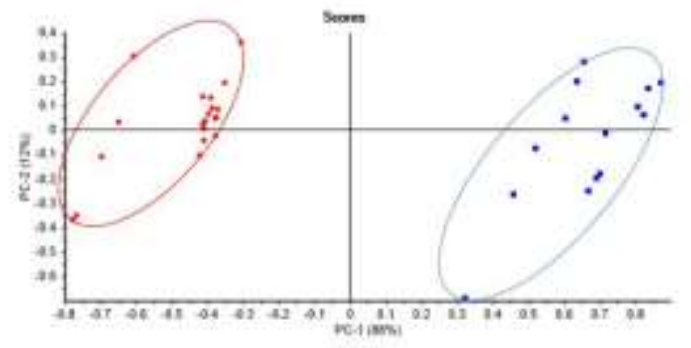


Keterangan Gambar :

: Arabika

: Robusta

Gambar 6. Hasil analisis PCA raw pada panjang gelombang 1000-1800 nm

Selanjutunya pada Gambar 7 pada panjang gelombang 1800-2500 nm untuk hasil analisis raw juga dapat terklasifikasi secara baik dimana bubuk kopi Arabika dan bubuk kopi Robusta dapat diklasifikasi $100 \%$. Total data yang dapat di analisa dengan kumulatif expalined variance 2 PC adalah sebesar $100 \%$. Data ini terklasifikasi secara baik dengan prosentase keberhasilan sebesar $100 \%$.

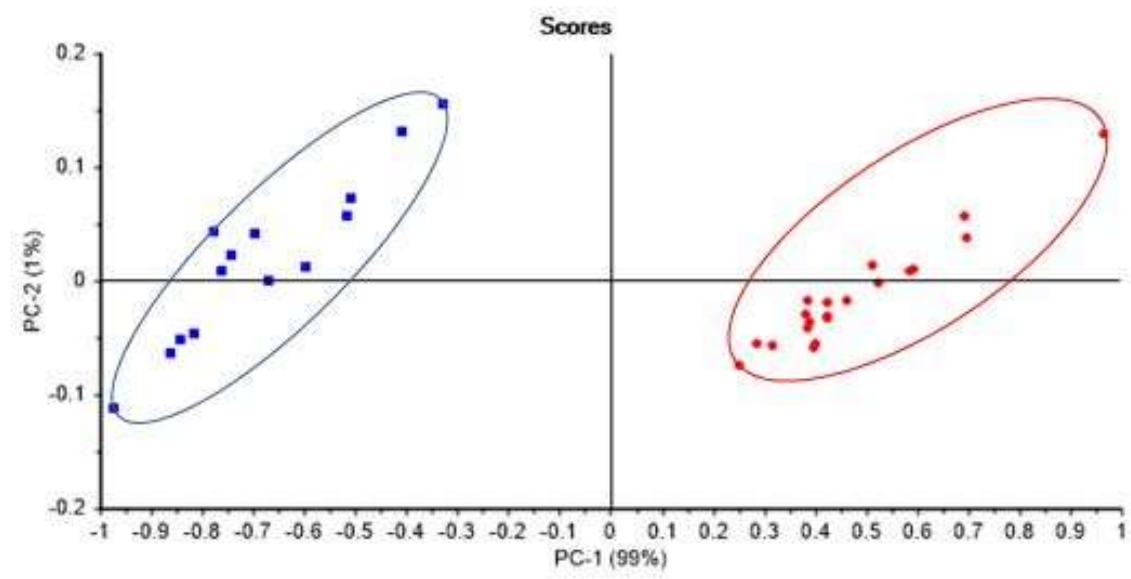

Keterangan Gambar :

- Arabika

- Robusta

Gambar 7. Hasil analisis PCA raw pada panjang gelombang 1800-2500 nm

Selanjutnya pada Gambar 8 hasil analisis PCA Derivative ke-2 pada panjang gelombang 1000-1800 nm terlihat bahwa kedua bubuk kopi terklasifikasi secara baik. Total data yang dapat di analisa dengan kumulatif expalined variance 2 PC adalah sebesar $43 \%$. Data ini terklasifikasi secara baik dengan prosentase keberhasilan sebesar $100 \%$.

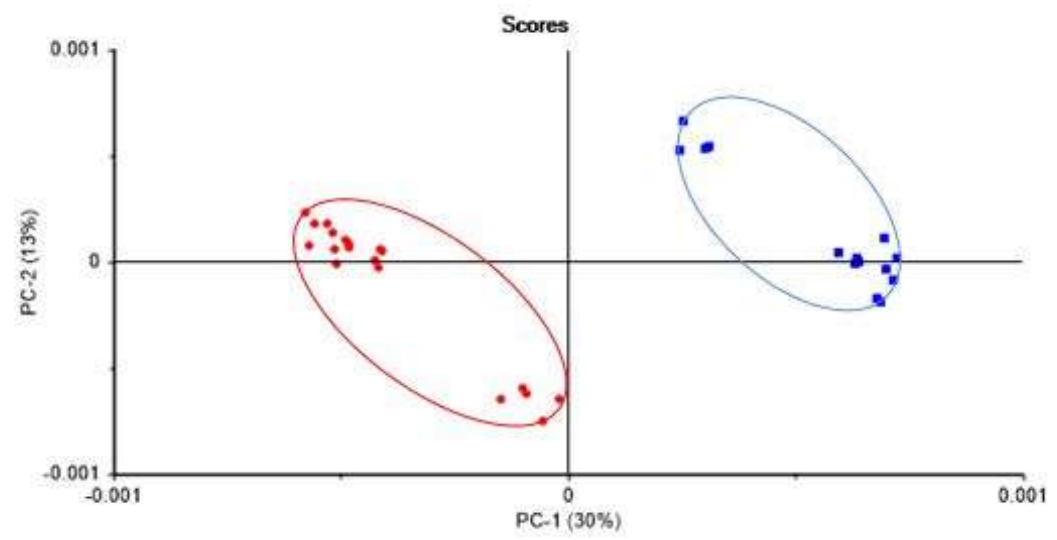

Keterangan Gambar :

- : Arabika

: Robusta

Gambar 8. Hasil analisis PCA Derivative ke-2 pada panjang gelombang 1000-1800 nm 
Kemudian pada Gambar 9 hasil analisis PCA Derivative ke-2 pada panjang gelombang 1800-2500 nm. Total data yang dapat di analisa dengan kumulatif expalined variance 2 PC adalah sebesar $96 \%$. Data ini terklasifikasi secara baik dengan prosentase keberhasilan sebesar $100 \%$. Secara rinci bubuk kopi Arabika dan bubuk kopi Robusta dapat terklasifikasi secara baik yaitu $100 \%$.

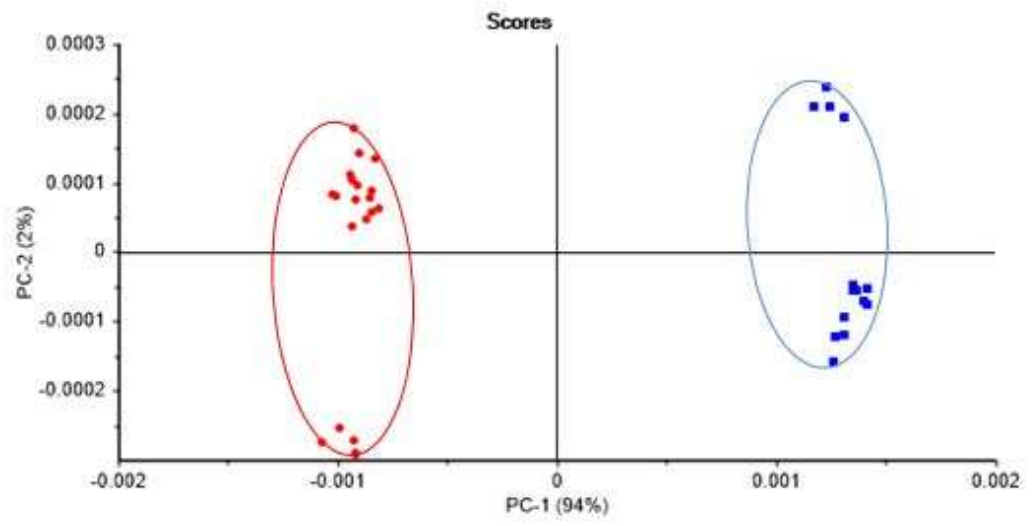

Keterangan Gambar :

- : Arabika

- : Robusta

Gambar 9. Hasil analisis PCA Derivative ke-2 pada panjang gelombang 1800-2500 nm

\section{KESIMPULAN DAN SARAN}

Spektrum bubuk kopi Arabika dan bubuk kopi Robusta mempunyai tipikal yang sama dimana puncak yang terbentuk pada spektrum sebagai informasi keberadaan kandungan zat-zat tertentu. Kandungan kafein pada bubuk kopi berada pada panjang gelombang 1430-1470 nm dan 1910-1965 nm. Kandungan lemak pada bubuk kopi berada pada panjang gelombang 1185$1230 \mathrm{~nm}, 1700-1780$ dan 2290-2390 nm. Kandungan protein pada bubuk kopi berada pada panjang gelombang 1430-1470 dan 1910-1965 nm. Kandungan asam amino berada pada panjang gelombang 2290-2390 nm. PCA mampu mengklasifikasikan bubuk kopi Arabika dan bubuk kopi Robusta dengan tingkat keberhasilan 100\%. Rentang panjang gelombang represintatif untuk klasifikasi PCA yaitu pada panjang gelombang 1730-1740 nm dan pada panjang gelombang 2310-2355 nm merupakan keberadaan kandungan lemak. Panjang gelombang 1930-1935 nm merupakan keberadaan kandungan kafein dan kandungan protein. Sedangkan panjang gelombang 2125-2135 nm merupakan keberadaan kandungan asam amino.

Perlu studi lebih lanjut tentang kemungkinan prediksi kadar kualitas kopi dengan menggunakan metode Partial Least Square Regression (PLSR) atau Principal Component Regression (PCR).

\section{DAFTAR PUSTAKA}

AEKI. 2013. Laporan Realisasi Ekspor Kopi Arabika Provinsi Aceh. Aceh (ID): AEKI.

[BPS] Badan Pusat Statistik. 2015. Statistik Indonesia. 